IMMACULATE CONCEPTIONS: THE POWER OF THE RELIGIOUS IMAGINATION IN EARLY MODERN SPAIN 

ROSILIE HERNÁNDEZ

\section{Immaculate Conceptions: The Power of the Religious Imagination in Early Modern Spain}

UNIVERSITY OF TORONTO PRESS

Toronto Buffalo London 
(C) University of Toronto Press 2019

Toronto Buffalo London

utorontopress.com

Printed in Canada

ISBN 978-1-4875-0477-9

(Printed on acid-free, $100 \%$ post-consumer recycled paper with vegetable-based inks.

\section{Library and Archives Canada Cataloguing in Publication}

Title: Immaculate conceptions : the power of the religious imagination in early modern Spain / Rosilie Hernandez.

Names: Hernández, Rosilie, author.

Series: Toronto Iberic ; 42.

Description: Series statement: Toronto Iberic ; 42 | Includes bibliographical references and index.

Identifiers: Canadiana 20190103426 | ISBN 9781487504779 (hardcover)

Subjects: LCSH: Mary, Blessed Virgin, Saint - In literature. | LCSH: Mary, Blessed Virgin, Saint - Art. | LCSH: Mary, Blessed Virgin, Saint - Devotion to - Spain. | LCSH: Devotional literature, Spanish - History and criticism. | LCSH: Spanish literature - Classical period, 1500-1700 - History and criticism. | LCSH: Immaculate Conception - In literature. | LCSH: Immaculate Conception in art. | LCSH: Painting, Spanish - 17th century. Classification: LCC PQ6063 .H47 2019 | DDC 860.9/351—dc23

University of Toronto Press acknowledges the financial assistance to its publishing program of the Canada Council for the Arts and the Ontario Arts Council, an agency of the Government of Ontario.

Canada Council for the Arts

Funded by the
Government of Canada
Conseil des Arts du Canada

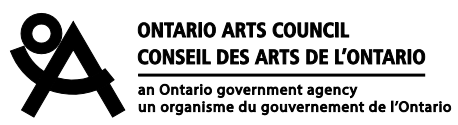

an Ontario government agency
un organlsme du gouvernement de l'Ontarlo

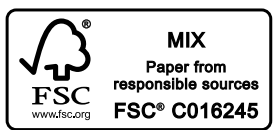


To Antonia, Manuela, and Joaquín

who came before this book was conceived

To Michat

who made its conception possible 
